\title{
FAKTOR YANG MEMENGARUHI PERSONAL FINANCIAL PLANNING PADA MASYARAKAT KOTA KEDIRI
}

\author{
Hafida Alviolita Dwi Ningrum \\ Universitas Negeri Surabaya \\ hafida.17080574074@mhs.unesa.ac.id
}

Abstract

Personal financial planning is essential to have for everyone to achieve their financial goals. This research focuses on the people of Kediri City because BPS data shows that the per capita income of Kediri City is the highest compared to other cities in East Java Province. This research aimed to determine the effect of selfesteem, financial literacy, income, and digital financial services on personal financial planning. This research uses the causality research method and 193 respondents as the sample with cluster sampling obtained from online and offline questionnaires. Data were analyzed using multiple linear regression and processed with SPSS. This research shows results that self-esteem and financial literacy variables have a positive effect on personal financial planning. While the variables income and digital financial services did not affect personal financial planning. The results of the research are expected to be used by the Government of Kediri City in preparing education for its people to have better personal financial planning.

Keyword: digital financial services; financial literacy; income; personal financial planning; self-esteem

\section{PENDAHULUAN}

Kondisi perekonomian suatu daerah dapat dilihat melalui seberapa besar Produk Domestik Regional Bruto (PDRB) yang dimiliki dalam kurun waktu tertentu (Departemen Statistik Bank Indonesia, 2015). Selain dapat digunakan untuk mengukur perekonomian dan pembangunan daerah, PDRB juga dapat mengukur tingkat kesejahteraan masyarakat di suatu daerah jika dibagi dengan jumlah penduduk daerah tersebut, atau yang secara umum disebut sebagai pendapatan per kapita (Azizah et al., 2018). Menurut data Badan Pusat Statistik (2018), Provinsi Jawa Timur merupakan provinsi dengan tingkat pendapatan per kapita terbesar nomor sembilan di Indonesia.

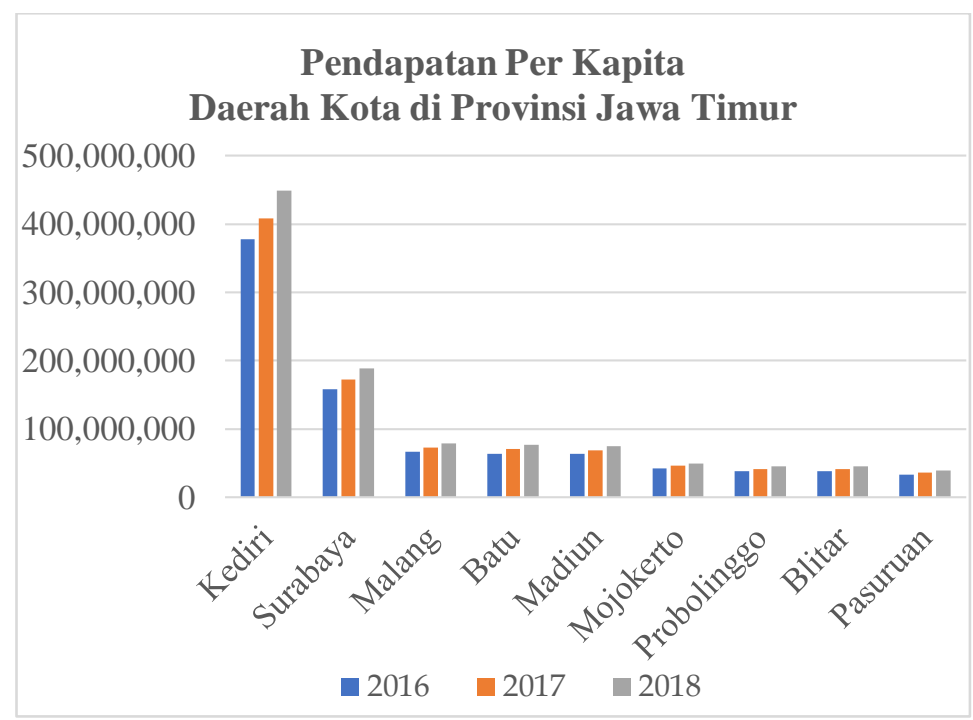

\section{Sumber: Badan Pusat Statistik Jawa Timur, 2018 (data diolah) \\ Gambar 1. PENDAPATAN PER KAPITA KOTA-KOTA DI PROVINSI JAWA TIMUR TAHUN 2016-2018}

Gambar 1, jika dibandingkan dengan delapan kota-kota lainnya di Provinsi Jawa Timur, yaitu Kota Surabaya, Malang, Batu, Madiun, Mojokerto, Probolinggo, Blitar, dan Pasuruan, Kota Kediri merupakan daerah dengan tingkat pendapatan per kapita tertinggi dari tahun ke tahun, yaitu 
Hafida Alviolita Dwi Ningrum. Faktor yang Memengaruhi Personal Financial Planning pada Masyarakat Kota Kediri

Rp377.321.812,34 per kapita tahun 2016, Rp488.578.356,64 per kapita tahun 2017, dan Rp448.578.356,64 per kapita tahun 2018 (Badan Pusat Statistik Jawa Timur, 2018). Tingginya tingkat pendapatan per kapita masyarakat di Kota Kediri tersebut menggambarkan bahwa masyarakat di Kota Kediri juga memiliki tingkat kesejahteraan yang tinggi. Dengan tingginya tingkat kesejahteraan tersebut, masyarakat memiliki lebih banyak kesempatan untuk menyisihkan sebagian pendapatan yang dimiliki saat ini untuk kebutuhan di masa depan (Brounen et al., 2016).

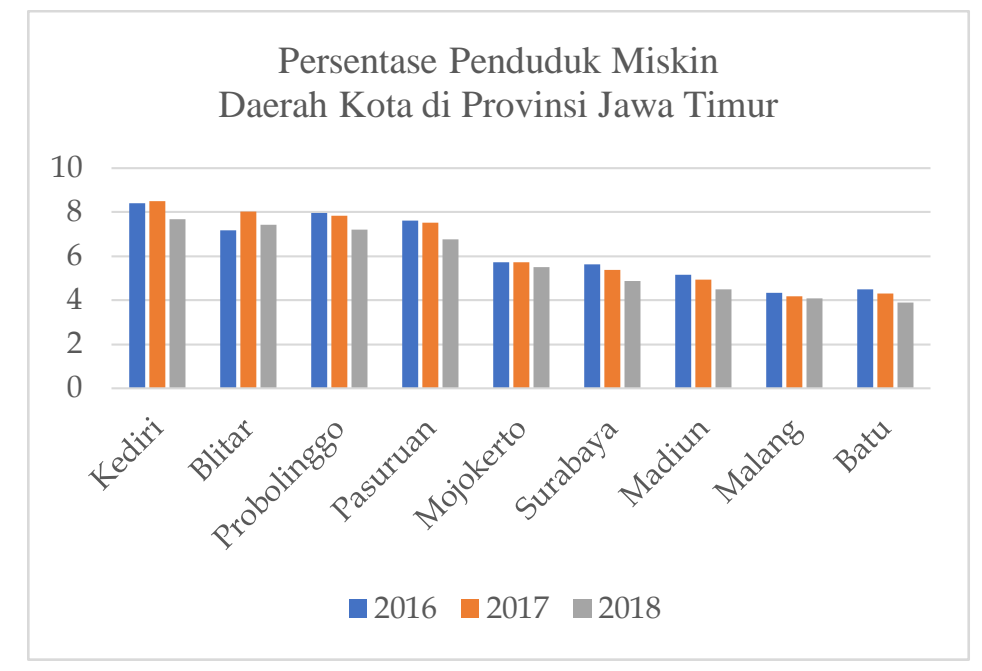

Sumber: Badan Pusat Statistik Jawa Timur, 2018 (data diolah)

\section{Gambar 2. PERSENTASE PENDUDUK MISKIN KOTA-KOTA DI PROVINSI JAWA TIMUR TAHUN 2016-2018}

Gambar 2, Kota Kediri memiliki persentase penduduk miskin tertinggi dari tahun ke tahun, yaitu 8,40\% tahun 2016, 8,49\% tahun 2017, dan 7,68\% di tahun 2018 (Badan Pusat Statistik Jawa Timur, 2018). Hal tersebut tidak sesuai dengan pernyataan bahwa semakin tinggi pendapatan per kapita di suatu daerah maka tingkat kemiskinan dapat berkurang karena masyarakat dapat memenuhi kebutuhan dasarnya dengan lebih mudah (Azizah et al., 2018).

Keputusan untuk menyisihkan sebagian pendapatan untuk kebutuhan di masa depan merupakan salah satu bentuk personal financial planning, yaitu upaya seseorang yang berkelanjutan dari waktu ke waktu untuk tetap dapat memenuhi kebutuhan di masa depan meskipun dalam keadaan tidak terduga (Palací et al., 2018). Perencanaan keuangan dibutuhkan agar individu dapat mengelola dan mengalokasikan dana yang dimiliki dengan tepat di masa produktif (Hutabarat \& Wijaya, 2020). Personal financial planning menentukan semua keputusan keuangan individu, termasuk penganggaran, asuransi, tabungan dan investasi, perencanaan pembelian aset, serta perencanaan pensiun (Kireeva, 2016).

Penelitian mengenai faktor yang memengaruhi personal financial planning menarik untuk diteliti karena masih jarang di Indonesia. Selain itu, topik penelitian tersebut relavan dilakukan pada masyarakat Kota Kediri, di mana tingkat pendapatan per kapita yang tinggi tidak dapat menjadikan persentase penduduk miskin yang dimiliki lebih baik, hal tersebut dapat dipengaruhi oleh kurangnya kesadaran masyarakat untuk merencanakan keuangan pribadinya (Wulandari \& Sutjiati, 2014). Berdasarkan beberapa penelitian terdahulu, ditemukan bahwa terdapat beberapa faktor yang memengaruhi personal financial planning, antara lain adalah self-esteem.

Variabel pertama yang diteliti adalah self-esteem (harga diri), yaitu bagaimana seseorang memberikan penilaian terhadap dirinya sendiri, seseorang dengan harga diri yang tinggi (high self-esteem) akan melihat dirinya dengan lebih positif, begitu pula sebaliknya (Jordan et al., 2015). Dalam hal yang berkaitan dengan uang, harga diri dapat memengaruhi bagaimana seseorang dalam memaknai uang. Harga diri rendah (low self-esteem) yang dimiliki seseorang akan menimbulkan rasa tidak layak untuk 
mendapatkan uang yang pada akhirnya menurunkan makna uang bagi seseorang tersebut, dan sebaliknya seseorang dengan harga diri tinggi (high self-esteem) akan lebih tinggi dalam memaknai uang (Meinarno \& Rahardjo, 2012). Namun begitu, Xinyu et al. (2009) menyatakan bahwa uang tidak selalu dapat menjadi solusi dari permasalahan terkait harga diri (self-esteem). Neymotin (2010) mengemukakan self-esteem berpengaruh signifikan terhadap personal financial planning.

Variabel kedua yang diteliti adalah literasi keuangan. Chen \& P.Volpe (1998) mengemukakan bahwa literasi keuangan merupakan pengetahuan individu tentang bagaimana mengelola dan mengambil keputusan terkait keuangan yang merupakan kebutuhan dasar bagi setiap individu untuk menghindari masalah keuangan (Muizzuddin et al., 2017). Literasi keuangan tidak hanya terkait bagaimana seseorang mengetahui, terampil, dan yakin terhadap lembaga, produk, dan layanan jasa keuangan, namun juga tercermin dari bagaimana seseorang dalam menyikapi dan memerlakukan keuangan yang bijak, yaitu mampu menyusun, mengelola, dan mengambil keputusan keuangan terkait penggunaan produk dan jasa keuangan untuk meningkatkan kesejahteraan (Otoritas Jasa Keuangan, 2017). Menurut Sobaya et al. (2016) dan Setyowati et al. (2018), literasi keuangan memengaruhi personal financial planning secara signifikan. Namun, Sudarto \& Reswari (2019) mengemukakan bahwa literasi keuangan tidak memengaruhi personal financial planning secara signifikan.

Variabel ketiga yang diteliti adalah pendapatan, yakni merupakan imbalan bagi seseorang, baik berupa uang maupun barang yang diterima dari perusahaan/kantor/majikan (Badan Pusat Statistik, 2019). Pendapatan merupakan faktor penting yang dapat meningkatkan konsumsi atau rasio tabungan seseorang (Aziz, 2019). Menurut Yohana (2010), individu yang memiliki ketersediaan pendapatan lebih besar akan memiliki kemungkinan untuk lebih dapat mengelola uangnya dengan bertanggung jawab. Lin et al. (2016) mengemukakan pendapatan berpengaruh signifikan terhadap personal financial planning. Namun, menurut Sudarto \& Reswari (2019), pendapatan tidak berpengaruh signifikan terhadap personal financial planning.

Variabel keempat yang diteliti adalah layanan keuangan digital. Menurut Muizzuddin et al. (2017), perkembangan industri keuangan merupakan faktor yang penting dalam menentukan pertumbuhan ekonomi negara. Dengan adanya perkembangan teknologi berupa aplikasi terkait pembayaran hingga artificial intelligence dan big data, pasar keuangan tradisional dapat tergantikan oleh penyedia layanan keuangan digital (Harahap et al., 2017). Layanan keuangan digital dapat digunakan sebagai media untuk memerluas wawasan seseorang terkait dengan literasi dan inklusi keuangan, serta dapat memermudah dan memercepat berjalannya transaksi keuangan (Mulasiswi, Cut Musni; Julialevi, 2020). Keloth et al. (2020) mengemukakan layanan keuangan digital berpengaruh signifikan terhadap personal financial planning. Tujuan penelitian ini adalah melihat pengaruh dari self-esteem, literasi keuangan, pendapatan, dan layanan keuangan digital terhadap personal financial planning pada masyarakat Kota Kediri.

\section{KAJIAN PUSTAKA DAN PENGEMBANGAN HIPOTESIS}

\section{Theory of Planned Behavior (TPB)}

Theory of planned behavior menjelaskan bahwa perilaku seseorang dipengaruhi oleh niat yang dimilikinya, niat tersebut selanjutnya membentuk motivasi yang dapat mendorong seseorang untuk mengupayakan perilaku yang telah direncanakan (Ajzen, 1991). Teori ini berdasarkan asumsi bahwa manusia biasanya berperilaku bijaksana dan memerhitungkan informasi yang didapat untuk memertimbangkan pengaruh dari tindakannya (Ajzen, 2005). Niat seseorang untuk berperilaku dibagi menjadi tiga faktor, yaitu faktor personal, sosial, dan informasi (Ajzen et al., 1992). Teori ini digunakan untuk menjelaskan variabel self-esteem dan literasi keuangan terhadap personal financial planning.

\section{Theory of Life Cycle Hypothesis}

Theory of life cycle hypothesis adalah teori yang menjelaskan bagaimana seseorang menyimpan dan menghabiskan pendapatan yang dimiliki sepanjang hidupnya. Terdapat tiga pola konsumsi 

Masyarakat Kota Kediri

berdasarkan usia seseorang, yaitu usia 0 hingga usia kerja, usia kerja, dan usia tidak produktif. Teori ini menunjukkan bahwa keputusan seseorang untuk membagi pendapatannya untuk konsumsi dan menabung terbentuk dari sudut pandang siklus hidup (Ando \& Modigliani-Brumberg, 1963). Teori ini digunakan untuk menjelaskan variabel pendapatan terhadap personal financial planning.

\section{Technology Acceptance Model}

Technology acceptance model adalah teori yang menjelaskan bahwa sikap seseorang terhadap penggunaan teknologi baru ditentukan oleh persepsi pengguna terkait kegunaan (percieved usefulness) dan mudahnya penggunaan (percieved easy of use), selanjutnya sikap akan menentukan niat perilaku pengguna untuk menggunakan teknologi didorong dengan motivasi diri (behavioral intention to use) yang diharapkan dapat memberikan penjelasan atas penerimaan pengguna terhadap suatu teknologi (Davis, 1985). Teori ini digunakan untuk menjelaskan variabel layanan keuangan digital terhadap personal financial planning.

\section{Personal Financial Planning}

Personal financial planning merupakan perencanaan yang dibuat oleh seseorang dalam upaya mencapai tujuan keuangan yang dimiliki dengan melihat kondisi saat ini dan memertimbangkan asumsi ekonomi yang realistis, seperti pendapatan masa depan, pertumbuhan investasi, dan inflasi, sehingga dapat menjadi dasar dalam penyusunan langkah-langkah yang perlu diambil untuk mencapai tujuan keuangan yang dimiliki dalam waktu yang diinginkan, dengan tidak meninggalkan fleksibililitas dalam menjalankan langkah-langkah tersebut, namun tetap berusaha keras untuk disiplin agar tujuan keuangan pribadi yang dimiliki segera tercapai (Harrison, 2005). Personal financial planning dihitung menggunakan skala likert. Menurut Lin et al. (2016), untuk mengukur personal financial planning dapat menggunakan indicator: kesadaran perencanaan keuangan pribadi; sudut pandang tentang perencanaan keuangan; preferensi manajemen keuangan; dan persepsi risiko.

\section{Self-Esteem}

Self-esteem adalah perasaan bahwa seseorang pantas dan butuh untuk hidup. Lebih spesifik, selfesteem dapat diartikan sebagai kepercayaan seseorang pada kemampuan dirinya untuk berpikir dan mengatasi tantangan dalam hidup, serta keyakinan bahwa berhak untuk merasakan kebahagiaan, merasa layak, pantas untuk memiliki hal yang diinginkan dan dibutuhkan, serta menikmati hal yang telah diupayakan (Branden, 1992). Seseorang dengan harga diri yang memadai cenderung memiliki strategi yang lebih tepat dalam memenuhi kebutuhannya. Orang tersebut akan menjaga diri untuk tetap aman dengan menghilangkan risiko yang mungkin terjadi dan akan memecahkan masalah daripada hanya mengkhawatirkannya (McKay \& Fanning, 2016).

\section{Literasi Keuangan}

Literasi keuangan diartikan secara luas sebagai pemahaman seseorang terhadap ekonomi dan bagaimana keputusan keuangan seseorang dapat dipengaruhi oleh keadaan ekonomi, diartikan lebih sempit sebagai pengetahuan seseorang terhadap pengelolaan uang dasar yang meliputi penganggaran tabungan, investasi, dan asuransi (Saeedi \& Hamedi, 2018). Literasi keuangan merupakan tujuan utama dari pendidikan keuangan yang menghasilkan pengetahuan dan pemahaman bersama motivasi akan meningkatkan keterampilan dan keyakinan sehingga seseorang dapat menentukan situasi keuangannya sendiri sehingga menghasilkan kesejahteraan keuangan (Aprea et al., 2016).

\section{Pendapatan}

Pendapatan merupakan jumlah maksimal konsumsi seseorang dalam periode tertentu dengan pola konsumsi yang sama dari awal hingga akhir periode (Solomons, 1961). Variabel pendapatan diukur dengan pendapatan dari berbagai sumber, mulai dari gaji, tunjangan, tunjangan anak, pendapatan investasi, pendapatan sewa, uang saku dari orang tua, atau pendapatan lainnya (Yohana, 2010).

\section{Layanan Keuangan Digital}

Layanan keuangan digital memberikan transformasi terhadap berbagai layanan keuangan, mulai dari sistem pembayaran, tabungan dan investasi, pembiayaan dan pendanaan proyek, deposito dan pinjaman, layanan perbankan, asuransi, serta manajemen risiko yang memungkinkan dapat diaksesnya 
layanan keuangan dengan lebih mudah dan dapat mendorong meningkatnya literasi keuangan pada masyarakat. Pengelolaan keuangan pribadi dapat diakses lebih mudah dengan berkembangnya layanan keuangan digital. Semakin banyaknya lembaga keuangan yang menawarkan pelayanan pengelolaan keuangan pribadi melalui digital, pelanggan tidak perlu untuk mendatangi perencana keuangan profesional secara langsung (Scardovi, 2017).

\section{Pengaruh antar Variabel}

Mruk (2006) menjelaskan self-esteem memiliki peranan penting dalam menentukan sikap atau perilaku yang akan diambil seseorang, hal tersebut dikarenakan penilaian seseorang terhadap dirinya akan memengaruhi sikap yang akan diambil. Maka, sikap seseorang terhadap bagaimana seseorang mengelola personal financial planning yang dimilikinya juga dapat dipengaruhi oleh bagaimana seseorang tersebut dalam menilai dirinya. Self-esteem dijelaskan oleh theory of planned behavior, di mana dalam teori tersebut, manusia juga akan dipengaruhi oleh faktor personal berupa sikap dalam menentukan perilakunya. Menurut Neymotin (2010), self-esteem berpengaruh signifikan terhadap personal financial planning.

H1 : Self-esteem berpengaruh terhadap personal financial planning.

Literasi keuangan adalah pengetahuan dan keterampilan pengelolaan keuangan yang dimiliki oleh seseorang sebagai kebutuhan untuk menghindari masalah keuangan (Yushita, 2017). Dengan demikian, literasi keuangan akan dapat meningkatkan kesadaran dan kemampuan seseorang dalam mengelola personal financial planning yang dimilikinya. Variabel literasi keuangan dijelaskan melalui theory of planned behavior, bahwa seseorang akan memiliki intelegensi yang berbeda-beda. Sobaya et al. (2016) dan Setyowati et al. (2018) mengemukakan literasi keuangan berpengaruh signifikan personal financial planning seseorang.

H2 : Literasi Keuangan berpengaruh terhadap personal financial planning.

Shelitha Smodic, et al. (2019) menyatakan bahwa pendapatan merupakan faktor eksternal yang penting dalam perencanaan keuangan, hal tersebut dikarenakan pendapatan dapat digunakan untuk menentukan prioritas pengeluaran masa depan. Maka, besar kecilnya pendapatan dapat memengaruhi penyusunan personal financial planning yang dimiliki oleh seseorang, karena prioritas yang dimiliki juga akan berbeda. Variabel pendapatan dijelaskan dengan theory of life cycle hypothesis yang menyatakan bahwa seseorang dapat mengalokasikan pendapatannya untuk jangka pendek maupun jangka panjang sesuai dengan personal financial planning yang dimiliki. Menurut Lin et al. (2016), pendapatan memiliki pengaruh yang signifikan terhadap personal financial planning.

H3 : Pendapatan berpengaruh terhadap personal financial planning.

Layanan keuangan digital adalah layanan yang memungkinkan manusia untuk mengakses pelayanan keuangan dengan lebih mudah (Baumol, 1952). Kemudahan akses layanan keuangan secara digital akan meningkatan pengetahuan dan kesadaran seseorang terkait penting dan semakin mudahnya menyusun personal financial planning. Layanan keuangan digital dijelaskan oleh theory of planned behavior, di mana dalam teori ini faktor informasi, khususnya media merupakan salah satu faktor yang dapat memengaruhi seseorang dalam merencanakan perilakunya. Keloth et al. (2020) mengemukakan layanan keuangan digital berpengaruh signifikan terhadap personal financial planning.

H4 : Layanan keuangan digital berpengaruh terhadap personal financial planning.

\section{METODE PENELITIAN}

Penelitian ini merupakan studi kausalitas, menggunakan data primer hasil penyebaran kuesioner secara online dan offline. Terdapat empat variabel independen, yaitu self-esteem, literasi keuangan, 
Hafida Alviolita Dwi Ningrum. Faktor yang Memengaruhi Personal Financial Planning pada Masyarakat Kota Kediri

pendapatan, dan layanan keuangan digital, sedangkan personal financial planning merupakan variabel dependen. Populasi dalam penelitian ini adalah masyarakat Kota Kediri. Sampel sebanyak 193 responden. Teknik pengumpulan sampel menggunakan purposive sampling, dengan kriteria berdomisili Kota Kediri dan memiliki pendapatan, baik dari gaji, uang saku dari orang tua, maupun pendapatan lainnya. Sampel tersebut diambil dengan teknik cluster sampling pada tiap-tiap kecamatan yang terdapat di Kota Kediri dengan hasil perhitungan 80 responden dari Kecamatan Mojoroto, 57 responden dari Kecamatan Kota, dan 56 responden dari Kecamatan Pesantren. Hal ini bertujuan pemerataan responden dalam mewakili keseluruhan wilayah di Kota Kediri.

Variabel self-esteem dihitung menggunakan skala likert. Kamila dan Mukhlis (2013) menyatakan variabel self-Esteem dapat diukur menggunakan indikator sebagai berikut: (a) Menganggap dirinya berharga, (2) Menghargai orang lain, (3) Mengontrol diri, (4) Menerima kritik, (5) Menyukai tantangan, (6) Mengekspresikan diri, (7) Mengetahui keterbatasaan diri, (8) Bersikap demokratis dan memiliki nilai, (9) Hidup efektif. Variabel literasi keuangan dihitung dengan skala likert. Menurut Chen \& P.Volpe (1998), untuk mengukur variabel literasi keuangan dapat menggunakan indikator: (1) Pengetahuan dasar mengenai keuangan, (2) Simpan pinjam, (3) Proteksi, (4) Investasi. Variabel pendapatan dihitung menggunakan skala ordinal. Rusdini (2020) menyatakan bahwa variabel pendapatan diklasifikasikan berdasarkan Upah Minimum Regional (UMR) yang berlaku di Kota Kediri, yaitu: (1) $\leq$ Rp.2.000.000, (2) Rp.2.000.001 - Rp.4.000.000, (3) Rp.4.000.001 - Rp.8.000.000, (4) > Rp.8.000.000. Variabel layanan keuangan digital dihitung menggunakan skala likert. Menurut Adhiputra (2015), indikator yang dapat digunakan untuk mengukur variabel layanan keuangan digital adalah: (1) Mudahnya penggunaan, (2) Merasakan manfaat, (3) Sikap saat menggunakan, (4) Penggunaan sebenarnya.

Dua tahap dalam pengambilan sampel penelitian, yaitu menguji validitas dan reliabilitas pada instrumen penelitian terhadap 30 sampel. Selanjutnya, dilakukan penyebaran kuesioner pada 193 sampel setelah data telah lolos uji. Data yang telah terkumpul selanjutnya ditabulasi lalu dijumlahkan setiap variabel untuk selanjutnya diuji validitas dan reliabilitas kembali untuk lolos uji asumsi klasik sehingga memenuhi model regresi linear berganda. Kemudian, menggunakan regresi linear berganda untuk menganalisis data, yaitu dengan menggunakan uji asumsi klasik yang meliputi uji normalitas, uji multikolonieritas, dan uji heteroskedastisitas. Lalu, menggunakan uji hipotesis untuk menguji data, yaitu dengan uji statistik F, uji statistik t, dan koefisien determinasi.

\section{HASIL DAN PEMBAHASAN}

Tabel 1.

DESKRIPTIF RESPONDEN

\begin{tabular}{llc}
\hline & \multicolumn{1}{c}{ Profil } & Frekuensi \\
\hline Usia & 15-27 Tahun & 153 \\
& 28-40 Tahun & 22 \\
& 41-53 Tahun & 10 \\
& 54-65 Tahun & 8 \\
Jenis Kelamin & Laki-laki & 58 \\
& Perempuan & 135 \\
Pendapatan & $\leq$ Rp.2.000.000 & 114 \\
& Rp.2.000.001 - Rp.4.000.000 & 41 \\
& Rp.4.000.001 - Rp.8.000.000 & 21 \\
& $>$ Rp.8.000.000 & 17 \\
\hline
\end{tabular}

Sumber: Data diolah

Tabel 1, karakteristik responden berdasarkan demografi meliputi usia, jenis kelamin, dan pendapatan. Dari pengolahan data, mayoritas responden berusia 15-27 tahun. Berdasarkan jenis kelamin, mayoritas responden berjenis kelamin perempuan. Berdasarkan pendapatan, diketahui bahwa responden memiliki pendapatan $\leq$ Rp.2.000.000, sesuai dengan Upah Minimum Regional (UMR) yang berlaku di Kota Kediri. 
Tabel 2.

HASIL UJI VALIDITAS DAN RELIABILITAS

\begin{tabular}{|c|c|c|c|c|c|c|c|}
\hline Variabel & Item & $\begin{array}{c}\text { Pearson } \\
\text { Correlation }\end{array}$ & $\begin{array}{c}\text { Cronbach's } \\
\text { Alpha }\end{array}$ & Variabel & Item & $\begin{array}{c}\text { Pearson } \\
\text { Correlation }\end{array}$ & $\begin{array}{c}\text { Cronbach's } \\
\text { Alpha }\end{array}$ \\
\hline Self- & SE1 & 0,641 & \multirow{10}{*}{0,749} & Literasi & LIT1 & 0,589 & \multirow{10}{*}{0,826} \\
\hline \multirow{9}{*}{ Esteem } & SE2 & 0,607 & & Keuangan & LIT2 & 0,600 & \\
\hline & SE3 & 0,354 & & & LIT3 & 0,445 & \\
\hline & SE4 & 0,417 & & & LIT4 & 0,617 & \\
\hline & SE5 & 0,273 & & & LIT5 & 0,676 & \\
\hline & SE6 & 0,621 & & & LIT6 & 0,651 & \\
\hline & SE7 & 0,501 & & & LIT7 & 0,686 & \\
\hline & SE8 & 0,798 & & & LIT8 & 0,678 & \\
\hline & SE9 & 0,681 & & & LIT9 & 0,689 & \\
\hline & SE10 & 0,738 & & & LIT10 & 0,682 & \\
\hline Layanan & LKD1 & 0,698 & \multirow{8}{*}{0,852} & Personal & PFP1 & 0,730 & \multirow{8}{*}{0,809} \\
\hline Keuangan & LKD2 & 0,718 & & Financial & PFP2 & 0,721 & \\
\hline \multirow[t]{6}{*}{ Digital } & LKD3 & 0,754 & & Planning & PFP3 & 0,758 & \\
\hline & LKD4 & 0,679 & & & PFP4 & 0,631 & \\
\hline & LKD5 & 0,685 & & & PFP5 & 0,788 & \\
\hline & LKD6 & 0,673 & & & PFP6 & 0,676 & \\
\hline & LKD7 & 0,671 & & & & & \\
\hline & LKD8 & 0,743 & & & & & \\
\hline
\end{tabular}

Sumber: Output SPSS (data diolah)

Tabel 2, nilai $\mathrm{r}$ hitung keseluruhan item pertanyaan pada variabel self-esteem, literasi keuangan, layanan keuangan digital, dan personal financial planning lebih besar daripada nilai $r$ tabel pada pengujian terhadap 193 responden, di mana $r$ tabel adalah sebesar 0,1406. Uji validitas menunjukkan hasil semua item dalam variabel menghasilkan $r$ hitung $>r$ tabel sesuai dengan Ghozali (2018:52). Dapat diartikan bahwa seluruh item pertanyaan yang digunakan valid sehingga dapat dijadikan alat ukur. Pada skala likert variabel self-esteem, literasi keuangan, layanan keuangan digital, dan personal financial planning menunjukkan nilai cronbach's alpha >0,70 sesuai dengan Ghozali (2018:46). Di mana cronbach's alpha pada variabel self-esteem sebesar 0,749, pada variabel literasi keuangan sebesar 0,826, pada variabel layanan keuangan digital sebesar 0,852 , dan pada variabel personal financial planning sebesar 0,809. Dengan demikian, data atau jawaban dari responden telah memenuhi kriteria, sehingga seluruh variabel telah reliabel.

Analisis grafik dengan grafik normal probability plot dan uji statistik dengan uji kolmogorov-smirnov (K-S) digunakan sebagai alat uji normalitas penelitian ini. Data yang dihasilkan dari grafik normal probability plot yaitu data berdistribusi disekitar garis diagonal dan mengikuti arah garis diagonal atau grafik histogramnya. Nilai uji kolmogorov-smirnov (K-S) adalah sebesar 0,68 dengan nilai signifikansi $0,320>0,05$, artinya data residual berdistribusi normal, sesuai dengan Ghozali (2018:164).

Hasil uji multikolonieritas dalam penelitian ini menggunakan nilai tolerance $\geq 0,10$ dan nilai VIF $\leq$ 10 sesuai dengan Ghozali (2018:108). Penelitian ini menunjukkan hasil nilai tolerance $\geq 0,10$ dan VIF $\leq 10$ pada seluruh variabel independen. Dengan demikian, gejala multikolonieritas tidak terjadi pada model regresi.

Grafik scatterplot dan uji spearman digunakan untuk mengetahui hasil uji heteroskedastisitas dalam penelitian ini. Pada grafik scatterplot, titik-titik terdistribusi secara acak di atas dan di bawah angka 0 pada sumbu Y. Nilai signifikansi pada uji spearman adalah $>0,05$ pada keseluruhan variabel independen. Maka, dapat diartikan bahwa tidak ada heteroskedastisitas. 
Hafida Alviolita Dwi Ningrum. Faktor yang Memengaruhi Personal Financial Planning pada Masyarakat Kota Kediri

Tabel 3 menunjukkan hasil regresi linear berganda, dengan persamaan regresi (1). Nilai konstanta sebesar 1,089 pada persamaan regresi dapat diartikan bahwa apabila variabel konstan, maka personal financial planning yang dilakukan oleh masyarakat Kota Kediri adalah sebesar 1,089. Nilai koefisien regresi self-esteem adalah sebesar 0,246, maka dapat diartikan bahwa setiap self-esteem meningkat 1000 kali, maka personal financial planning akan meningkat sebesar 246 kali. Nilai koefisien regresi literasi keuangan adalah sebesar 0,239, maka diartikan bahwa setiap literasi keuangan meningkat 1000 kali, maka personal financial planning akan meningkat sebesar 239 kali.

$\mathrm{Y}=1,089+0,246 \mathrm{SE}+0,239 \mathrm{LIT}+\mathrm{e}$

Tabel 3.

HASIL UJI REGRESI LINIER BERGANDA

\begin{tabular}{llccc}
\hline \multicolumn{1}{c}{ Model } & $\begin{array}{c}\text { Unstandardized } \\
\text { Coefficients }\end{array}$ & Prob & Sig. \\
\hline 1 & (Constant) & 1,089 & 0,859 & 0,391 \\
& Self-Esteem & 0,246 & 4,942 & 0,000 \\
& Literasi Keuangan & 0,239 & 4,311 & 0,000 \\
& Pendapatan & 0,196 & 1,152 & 0,251 \\
& Layanan Keuangan Digital & 0,074 & 1,432 & 0,154 \\
& F test & 0,474 & 44,242 & 0,000 \\
& Adj R Square & &
\end{tabular}

Sumber: Output SPSS (data diolah)

Nilai $F$ hitung yang dihasilkan dari uji statistik $F$ adalah 44,242 dengan nilai signifikansi 0,000. Secara bersama-sama, seluruh variabel independen dapat memengaruhi personal financial planning. Variabel self-esteem menunjukkan nilai t hitung sebesar 4,942 dengan signifikansi $0,000<0,05$ sebagai hasil dari uji statistik t, sedangkan variabel literasi keuangan memiliki nilai t hitung sebesar 4,311 dengan signifikansi $0,000<0,05$. Artinya variabel self-esteem dan literasi keuangan memengaruhi personal financial planning secara signifikan, sehingga hipotesis nol (H0) ditolak. Sedangkan untuk variabel pendapatan dan layanan keuangan digital tidak memengaruhi personal financial planning secara signifikan, dikarenakan nilai signifikansi > 0,05 sehingga hipotesis nol (H0) tidak ditolak. Nilai Adjusted $R$ Square sebesar 0,474 atau 47,4\%. Hal tersebut memiliki arti bahwa variabel independen dalam penelitian ini menjelaskan variabel dependen sebesar 47,4\%, sedangkan sebanyak 52,6\% dijelaskan variabel independen di luar penelitian ini.

\section{Pengaruh Self-Esteem terhadap Personal Financial Planning}

Self-esteem terbukti memengaruhi personal financial planning secara signifikan, artinya hipotesis satu (H1) diterima. Hal tersebut sejalan dengan penelitian Neymotin (2010), self-esteem berpengaruh signifikan terhadap personal financial planning, di mana sesuai dengan Theory of Planned Behavior self-esteem merupakan faktor personal yang dapat memengaruhi perilaku keuangan seseorang dengan memertimbangkan pikiran rasional.

Hasil tersebut membuktikan bahwa responden dalam penelitian ini menggunakan faktor personal berupa self-esteem dalam penyusunan personal financial planning. Hasil penelitian menunjukkan bahwa masyarakat Kota Kediri yang menjadi responden dalam penelitian ini memiliki self-esteem dalam kategori sedang dengan nilai rata-rata pada variabel self-esteem sebesar 2,89, sehingga sehingga masyarakat Kota Kediri memiliki kemampuan untuk berpikir dan mengatasi tantangan dalam hidup dan memiliki strategi yang lebih tepat dalam memenuhi kebutuhannya. Hal tersebut yang mendorong masyarakat Kota Kediri untuk memiliki personal financial planning yang baik pula sebagai strategi yang digunakan untuk memenuhi kebutuhan hidupnya, yaitu tujuan keuangan baik jangka pendek maupun panjang. Berdasarkan hasil kuesioner, responden dalam penelitian ini merasa dapat mengaktualisasikan dirinya terkait dengan pengelolaan keuangan, dapat memanfaatkan uang yang dimiliki dengan baik, dan merasa senang apabila dapat mengelola keuangannya dengan baik, 
sehingga mereka selalu terbuka untuk dapat menerima masukan orang lain terkait penelolaan keuangan.

Hasil ini sesuai dengan theory of planned behavior di mana self-esteem merupakan faktor personal yang dapat memengaruhi perilaku keuangan seseorang dengan memertimbangkan pikiran rasional (Branden, 1992). Tingkat self-esteem yang tinggi pada masyarakat Kota Kediri diharapkan dapat digunakan untuk memersiapkan pengelolaan keuangan sebagai upaya pencapaian tujuan keuangan dengan memerhatikan personal financial planning yang dimiliki, karena tingkat self-esteem dapat memengaruhi strategi keuangan yang akan diambil oleh seseorang dengan tujuan pemenuhan kebutuhan hidup yang dimiliki.

\section{Pengaruh Literasi Keuangan terhadap Personal Financial Planning}

Literasi keuangan terbukti memengaruhi personal financial planning secara signifikan, artinya hipotesis dua (H2) diterima. Hal ini sejalan dengan penelitian Sobaya et al. (2016), Setyowati et al. (2018), dan Mendari \& Soejono (2019), literasi keuangan berpengaruh signifikan terhadap personal financial planning, sesuai dengan Theory of Planned Behavior di mana literasi keuangan merupakan faktor sosial yang dapat memengaruhi keputusan keuangan yang diambil oleh seseorang.

Hasil tersebut membuktikan bahwa responden dalam penelitian ini menggunakan faktor sosial berupa literasi keuangan dalam penyusunan personal financial planning. Hasil penelitian menunjukkan bahwa masyarakat Kota Kediri yang menjadi responden dalam penelitian ini memiliki literasi keuangan dalam kategori sedang dengan nilai rata-rata pada variabel literasi keuangan sebesar 2,91, hal tersebut memberikan pemahaman yang selanjutnya menjadi keterampilan dan keyakinan, sehingga seseorang dapat memutuskan keuangannya dengan baik dengan tujuan menghasilkan kesejahteraan keuangan. Dibuktikan pada hasil kuesioner yang disebar, masyarakat Kota Kediri telah memiliki kesadaran terkait pengelolaan dan perencanaan keuangan sebagai pertimbangan dalam mengeluaran biaya sehari-hari merupakan dampak positif yang ditimbulkan dari baiknya literasi keuangan yang dimiliki. Berdasarkan hasil kuesioner, responden dalam penelitian ini memiliki pengetahuan yang baik terkait keuangan dan perencanaan keuangan, serta manfaat yang didapatkan ketika merencanakan keuangan dengan baik.

Tingginya tingkat literasi keuangan pada masyarakat Kota Kediri diharapkan dapat diterapkan dengan baik pada personal financial planning yang dimiliki sehingga memiliki kesiapan terkait keuangan sebagai upaya pencapaian tujuan keuangan yang dimiliki, baik dalam jangka pendek maupun jangka panjang, dikarenakan tingkat literasi keuangan dapat berpengaruh terhadap pemahaman dan kesadaran seseorang terhadap pentingnya merencanakan keuangan.

\section{Pengaruh Pendapatan terhadap Personal Financial Planning}

Pendapatan tidak terbukti memengaruhi personal financial planning secara signifikan, sehingga hipotesis tiga (H3) ditolak. Hasil tersebut sesuai dengan penelitian Sudarto \& Reswari (2019), pendapatan tidak berpengaruh signifikan terhadap personal financial planning. Implikasi pada penelitian ini yaitu hasil tidak sesuai dengan Theory of Life Cycle Hypotesis yang mendasari bahwa cara seseorang dalam membagi pendapatannya antara pengeluaran dan tabungan memerlukan perencanaan keuangan yang bertujuan untuk tercapainya tujuan keuangan seseorang (Mat Nawi, 2018).

Hasil tersebut membuktikan bahwa responden tidak menggunakan personal financial planning sebagai dasar dalam membagi pendapatan yang dimilikinya sesuai dengan porsi pengeluaran dan tabungan yang telah direncanakan, sehingga tinggi rendahnya tingkat pendapatan yang dimiliki tidak memengaruhi baik buruknya realisasi personal financial planning yang telah disusun. Hasil yang didapatkan dapat terjadi karena 59,07\% masyarakat Kota Kediri yang menjadi responden dalam penelitian ini memiliki pendapatan pada interval satu, sedangkan $21,24 \%$ memiliki pendapatan pada interval dua, $10,88 \%$ memiliki pendapatan pada interval tiga, dan $8,81 \%$ memiliki pendapatan pada interval empat, atau dapat diartikan bahwa data yang diperoleh hampir sejenis. Lalu, masih terdapat 

Masyarakat Kota Kediri

faktor lain yang dapat memengaruhi keputusan seseorang untuk merencanakan keuangannya, seperti halnya literasi keuangan yang akan sangat berdampak pada keputusan seseorang dalam personal financial planning yang dimilikinya. Selain itu, lingkungan sekitar juga sangat berpotensi dalam memengaruhi motivasi seseorang terkait penyusunan personal financial planning. Usia juga dapat menjadi faktor lain yang dapat memengaruhi personal financial planning seseorang, seperti halnya usia dalam Theory of Life Cycle Hypotesis dapat menjadi faktor yang mendasari pola konsumsi seseorang, di mana diperlukan personal financial planning dalam menentukan pola konsumsi tersebut (Mat Nawi, 2018).

\section{Pengaruh Layanan Keuangan Digital terhadap Personal Financial Planning}

Layanan keuangan digital tidak terbukti memengaruhi personal financial planning secara signifikan. Hasil tersebut tidak sesuai dengan penelitian Keloth et al. (2020), layanan keuangan digital berpengaruh signifikan terhadap personal financial planning. Temuan ini tidak sesuai dengan teori Technology Acceptance Model yang menyatakan bahwa persepsi pengguna terkait kegunaan (percieved usefulness) akan menentukan niat perilaku pengguna untuk menggunakan teknologi (Adhiputra, 2015).

Hasil tersebut membuktikan bahwa responden dalam penelitian ini tidak terpengaruh oleh persepsi terkait kegunaan (percieved usefulness) dalam penyusunan personal financial planning, sehingga walaupun masyarakat Kota Kediri yang menjadi responden dalam penelitian ini cukup setuju bahwa layanan keuangan berguna, yaitu sesuai dengan nilai rata-rata variabel layanan keuangan digital sebesar 2,81 atau dalam kategori sedang, namun mereka tetap tidak menggunakannya sebagai media untuk memermudah penyusunan personal financial planning. Hasil kuesioner menunjukkan bahwa responden dalam penelitian ini memiliki pemahaman bahwa layanan keuangan digital dapat memudahkan transaksi dan pengelolaan keuangan, serta merasa perlu menggunakannya. Namun, pada kenyataannya responden belum menggunakkan layanan keuangan digital tersebut dalam kehidupan sehari-hari.

Berdasarkan hasil dari wawancara, diperoleh fakta bahwa masyarakat Kota Kediri kurang memiliki pengetahuan mengenai cara mengaplikasikan layanan keuangan digital, sehingga masyarakat Kota Kediri tidak merasa perlu menggunakan layanan keuangan digital dalam mengelola keuangannya. Tingginya literasi keuangan pada masyarakat Kota Kediri juga dapat memengaruhi hasil bahwa layanan keuangan digital tidak berpengaruh terhadap personal financial planning, karena dengan literasi keuangan yang baik, masyarakat Kota Kediri tetap dapat merencanakan keuangannya dengan baik meskipun tidak menggunakan layanan keuangan digital.

\section{KESIMPULAN}

Self-esteem merupakan faktor yang berpengaruh terhadap personal financial planning pada masyarakat Kota Kediri. Hal tersebut dikarenakan masyarakat Kota Kediri menggunakan faktor personal berupa self-esteem yang dimiliki untuk membuat strategi keuangan yang baik. Literasi keuangan juga berpengaruh terhadap personal financial planning yang dimiliki oleh masyarakat Kota Kediri. Temuan tersebut disebabkan oleh masyarakat Kota Kediri menggunakan pengetahuan keuangan yang dimiliki untuk mengelola perencanaan keuangannya dengan baik. Pendapatan tidak berpengaruh terhadap personal financial planning masyarakat Kota Kediri, dikarenakan pembagian pendapatan yang dilakukan tidak berdasarkan perencanaan. Layanan keuangan digital tidak berpengaruh terhadap personal financial planning yang dimiliki oleh masyarakat Kota Kediri, karena persepsi tentang kegunaan (percieved usefulness) tidak dapat mendorong masyarakat Kota Kediri untuk menyusun personal financial planning.

Temuan ini diharapkan dapat mendorong masyarakat Kota Kediri untuk meningkatkan pengetahuan dan kesadaran akan pentingnya mengelola dan merencanakan keuangan, sekaligus menjadi bahan pertimbangan bagi Pemerintah Kota Kediri dan OJK untuk memberikan edukasi mengenai pentingnya mengelola dan merencanakan keuangan dengan baik. Keterbatasan dari penelitian ini adalah sampel yang cukup sedikit dan hampir sejenis, khususnya terkait pendapatan. Direkomendasikan bagi peneliti 
selanjutnya untuk menggunakan variabel usia, sikap keuangan, dan pengalaman keuangan ketika meneliti kembali mengenai personal financial planning, sehingga diperoleh hasil yang lebih akurat terkait faktor yang memengaruhi personal financial Planning.

\section{DAFTAR PUSTAKA}

Adhiputra, M. W. (2015). Aplikasi Technology Acceptance Model Terhadap Pengguna Layanan Internet Banking. Kalbi Socio, 2(1), 52-63.

Ajzen, I. (1991). The Theory of Planned Behavior Organizational Behavior and Human Decision Processes. Organizational Behavior and Human Decision Processes, 50(2), 179-211.

Ajzen, I. (2005). Attitudes, Personality \& Behavior ( $2^{\text {nd }}$ ed.): Open University Press, 1-146.

Ajzen, I., Madden, T. J., \& Ellen, P. S. (1992). A Comparison of the Theory of Planned Behavior and the Theory of Reasoned Action. Personality and Social Psychology Bulletin, 18(1), 3-9. https://doi.org/10.1177/0146167292181001

Ando, A., \& Modigliani-Brumberg. (1963). The "Life Cycle" Hypothesis of Saving: Aggregate Implications and Tests. The American Economic Review, 53(1), 55-84.

Aprea, C., Wuttke, E., Breuer, K., Koh, N. K., Davies, P., \& Greimel-Fuhrmann, B. (2016). Financial literacy to financial capability: Building financial stability and security. In J. S. Lopus (Ed.), International Handbook of Financial Literacy. 83-96. https://doi.org/10.1007/978-981-100360-8_7

Aziz, I. (2019). Pengaruh Uang Saku, Gaya Hidup, dan Perilaku Menabung terhadap Pola Konsumsi Non Makanan Mahasiswa (Studi Pada: Mahasiswa Fakultas Ekonomi Dan Bisnis Universitas Brawijaya). Jurnal Ilmiah Mahasiswa FEB UB,8(1), 1-16.

Azizah, E. W., Sudarti, \& Kusuma, H. (2018). Pengaruh Pendidikan, Pendapatan Perkapita dan Jumlah Penduduk terhadap Kemiskinan di Provinsi Jawa Timur. Jurnal Ilmu Ekonomi, 2(1), 167-180. http://ejournal.umm.ac.id/index.php/jie/article/view/6976

Badan Pusat Statistik. (2010). Pdrb. In Bps (Issue 2, p. 1). https://www.bps.go.id/subject/52/produkdomestik-regional-bruto--lapangan-usaha-.html. Diakses pada 9 Oktober 2020

Badan Pusat Statistik. (2018). Produk Domestik Regional Bruto Provinsi-Provinsi di Indonesia menurut

Pengeluaran. https://www.bps.go.id/publication/2019/10/18/c2395c5a8c35fc4c043de204/produk-domestikregional-bruto-provinsi-provinsi-di-indonesia-menurut-pengeluaran--2014-2018.html. Diakses pada 7 Oktober 2020

Badan Pusat Statistik. (2019). Statistik Pendapatan Februari 2019. https://www.bps.go.id/publication/2019/05/31/4f7829e7743f9dfbd498577e/statistikpendapatan-februari-2019.html. Diakses pada 7 Oktober 2020

Badan Pusat Statistik Provinsi Jawa Timur. (2018). Persentase Penduduk Miskin Kota di Provinsi Jawa Timur, Survei Sosial Ekonomi Nasional (Susenas). https://jatim.bps.go.id/statictable/2019/10/11/1857/jumlah-dan-persentase-penduduk-miskin-diprovinsi-jawa-timur-menurut-kabupaten-kota-2017-dan-2018-.html. Diakses pada 15 Oktober 2020 
Hafida Alviolita Dwi Ningrum. Faktor yang Memengaruhi Personal Financial Planning pada Masyarakat Kota Kediri

Badan Pusat Statistik Provinsi Jawa Timur. (2018). PDRB Perkapita Provinsi Jawa Timur https://jatim.bps.go.id/dynamictable/2018/01/16/221/pdrb-perkapita-atas-dasar-harga-berlakumenurut-kabupaten-kota-di-jawa-timur-2010-2016.html. Diakses pada 7 Oktober 2020

Badan Pusat Statistik Provinsi Jawa Timur. (2018). Produk Domestik Regional Bruto Jawa Timur Menurut Kabupaten/Kota 2014-2018. In BPS Provinsi Jawa Timur. https://jatim.bps.go.id/statictable/2019/10/09/1711/produk-domestik-regional-bruto-atas-dasarharga-berlaku-provinsi-jawa-timur-menurut-kabupaten-kota-miliar-2014-2018.html. Diakses pada 9 Oktober 2020

Baumol, W. J. (1952). The Transactions Demand for Cash: An Inventory Theoretic Approach. The Quarterly Journals of Economic, 66(4), 545-556.

Branden, N. (1992). The Power of Self-Esteem: An Inspiring Look At Our Most Important Psychological Resource. Health Communications, Inc, 1-96.

Brounen, D., Koedijk, K. G., \& Pownall, R. A. J. (2016). Household financial planning and savings behavior. Journal of International Money and Finance, 69(11033), 95-107. https://doi.org/10.1016/j.jimonfin.2016.06.011

Chen, H., \& P.Volpe, R. (1998). An Analysis of Personal Financial Literacy Among College Student. Zhongguo Jiguang/Chinese Journal of Lasers, 43(8), 107-128. https://doi.org/10.3788/CJL201643.0811001

Davis, F. D. (1985). A Technology Acceptance Model for Empirically Testing New End-User Informations Systems: Theory and Results. Science, 1-291. https://doi.org/10.1126/science.146.3652.1648

Departemen Statistik Ekonomi dan Moneter Bank Indonesia. (2015). Produk Domestik Regional Bruto (PDRB). http://www.bi.go.id

Ghozali, I. (2018). Aplikasi Analisis Multivariate dengan Program IBM SPSS 25 (9th ed.). Semarang: Badan Penerbit Universitas Diponegoro, 1-490.

Harahap, B. A., Idham, P. B., Kusuma, A. C. M., \& Rakhman, R. N. (2017). Perkembangan Financial Technology Terkait Central Bank Digital Currency (CBDC) Terhadap Transmisi Kebijakan Moneter Dan Makroekonomi. Working Paper Bank Indonesia, 2, 1-80.

Harrison, D. (2005). Personal Financial Planning: Theory and Practice. Pearson Education Limited, 1-415. http://www.cilip.org.uk

Hutabarat, A. S. S., \& Wijaya, C. (2020). Analysis the effect of financial literacy on financial planning for retirement (case study lecturers and administrative staffs in Universitas Indonesia). International Journal of Management, 11(5), 741-750. https://doi.org/10.34218/IJM.11.5.2020.066

Jordan, C. H., Zeigler-Hill, V., \& Cameron, J. J. (2015). Self-Esteem. In International Encyclopedia of the Social \& Behavioral Sciences: Second Edition, 21(2), 522-528. https://doi.org/10.1016/B978-0-08-097086-8.25090-3

Kamila, I. I., \& Mukhlis. (2013). Perbedaan Harga Diri (Self Esteem) Remaja Ditinjau dari Keberadaan Ayah. Jurnal Psikologi UIN Sultan Syarif Kasim Riau, 9(2), 100-112.

Keloth, S., Menaka, B., Mithila, P., Thangam, A., \& Francis, R. (2020). Revolutionizing financial planning and investment with the aspects of digital financial inclusion. International Journal of 
Scientific and Technology Research, 9(4), 2263-2266.

Kireeva, E. V. (2016). Effective Management of Personal Finance. Researchgate. 1-5.

Lin, W.-R., Yang, F.-J., \& Chang, H.-C. (2016). A Discussion of College Students' Financial Planning Awareness and Financial Planning Ability: A Case Study of a University in Taiwan. Journal of Accounting Finance \& Management Strategy, 11(1), 119-140. http://uprm.edu/library/relay.php?url=\%7BtargetURL\%7D/docview/1818677905?accountid=2 8498

Mat Nawi, H. (2018). Financial Planning Framework: Empirical Evidence on Muslim Households in Malaysia. Canadian Social Science, 14(5), 11-16. https://doi.org/10.3968/10340

McKay, M., \& Fanning, P. (2016). Self-Esteem (4th ed.). New Harbinger Publications, Inc, 1-358.

Meinarno, E. A., \& Rahardjo, W. (2012). Symbolic Meaning of Money , Self-esteem , and Identification with Pancasila Values. Procedia Social and Behavioral Sciences. 65(ICIBSoS), 106-115. https://doi.org/10.1016/j.sbspro.2012.11.099

Mendari, A. S., \& Soejono, F. (2019). Hubungan Tingkat Literasi dan Perencanaan Keuangan. Modus Journals, 31(2), 227-240.

Mruk, C. J. (2006). Self-esteem: research, theory, and practice. In Choice Reviews Online (Vol. 32, Issue 10), 1-270. Springer Publishing Company. https://doi.org/10.5860/choice.32-5938

Muizzuddin, T., Ghasarma, R., Putri, L., \& Adam, M. (2017). Financial Literacy: Strategies and Concepts in Understanding the Financial Planning with Self-Efficacy Theory and Goal Setting Theory of Motivation Approach. International Journal of Economics and Financial Issues, 7(4), 182-188. http:www.econjournals.com

Mulasiswi, Cut Musni; Julialevi, K. O. (2020). Optimalisasi Financial Teknologi ( Fintech ) Terhadap Peningkatan Literasi Dan Inklusi Keuangan Usaha Menengah Purwokerto. Performance, 27(1), $12-20$.

Neymotin, F. (2010). Linking self-esteem with the tendency to engage in financial planning. Journal of Economic Psychology, 31(6), 996-1007. https://doi.org/10.1016/j.joep.2010.08.006

Otoritas Jasa Keuangan. (2017). Strategi Nasional Literasi Keuangan Indonesia (Revisit 2017). In Otoritas Jasa Keuangan (pp. 1-99).

Palací, F., Jiménez, I., \& Topa, G. (2018). Too soon to worry? Longitudinal examination of financial planning for retirement among Spanish aged workers. PLoS ONE Journal, 13(12), 1-17. https://doi.org/10.1371/journal.pone.0209434

Rusdini, D. A. (2020). Faktor yang Memengaruhi Financial Satisfaction pada Masyarakat Kabupaten Pamekasan. Jurnal Ilmu Manajemen, 9(1), 1-9.

Saeedi, A., \& Hamedi, M. (2018). Financial literacy: Empowerment in the stock market. Switzerland: Springer International Publishing. https://doi.org/10.1007/978-3-319-77857-0

Scardovi, C. (2017). Digital Transformation in Financial Services. In Global Positioning for Financial Services. London: Springer International Publishing. 1-154. https://doi.org/10.1142/9789812793669_0001

Setyowati, A., Harmadi, H., \& Sunarjanto, S. (2018). Islamic Financial Literacy and Personal 
Hafida Alviolita Dwi Ningrum. Faktor yang Memengaruhi Personal Financial Planning pada Masyarakat Kota Kediri

Financial Planning: A Socio-Demographic Study. Jurnal Keuangan Dan Perbankan, 22(1), 63 72. https://doi.org/10.26905/jkdp.v22i1.1625

Shelitha Smodic, Forst, E., Rauschenberger, J., \& McCoy, M. (2019). Financial Planning with Ambiguous Loss from Alzheimer's Disease: Implications, Applications, and Interventions. American Journal of Economics and Control Systems Management, 1, 29-36. https://www.researchgate.net/publication/335589221_Financial_Planning_with_Ambiguous_L oss_from_Alzheimer's_Disease_Implications_Application_and_Interventions

Sobaya, S., Hidayanto, M. F., \& Safitri, J. (2016). Pengaruh Literasi Keuangan dan Lingkungan Sosial terhadap Perencanaan Keuangan Pegawai di Universitas Islam Indonesia Yogyakarta. Madania, 20(01), 1-14.

Solomons, D. (1961). Economic and Accounting Concepts of Income. University of Pensylvania Journal, 374-383.

Sudarto, \& Reswari, A. D. (2019). Faktor-faktor yang Mempengaruhi Perencanaan Keuangan Pribadi. Sustainable Competitive Advantage-9, 9(9), 157-167.

Wulandari, F. A., \& Sutjiati, R. (2014). Pengaruh Kesadaran Masyarakat dalam Perencanaan Keuangan Keluarga terhadap Kesejahteraan (Studi pada Warga Komplek BCP, Jatinangor. Siasat Bisnis, 18(1), 21-31.

Xinyue, Zhou, Kathleen, D. Vohs, \& Roy, F. Baumeister. (2009). The Symbolic Power of Money Reminders of Money Alter Social Distress and Physical Pain. Psychological Science, 20(6), 1-7.

Yohana, I. (2010). Pengaruh Locus Of Control, Financial Knowledge, Income terhadap Financial Management Behavior. Jurnal Bisnis dan Akuntansi, 12(3), 131-144.

Yushita, A. N. (2017). Pentingnya Literasi Keuangan Bagi Pengelolaan Keuangan Pribadi. Jurnal Nominal, VI(9), 1689-1699. 